A. V. Rudakova, R.A.Belykh, A.A. Tsyganenko

\title{
FTIR STUDY OF HCN ADSORPTION ON MAGNESIUM FLUORIDE
}

St. Petersburg State University,

7-9, Universitetskaya nab., St. Petersburg, 199034, Russian Federation

The mechanism of $\mathrm{HCN}$ interaction with $\mathrm{MgF}_{2}$ pretreated at $773 \mathrm{~K}$ has been studied by means of FTIR spectroscopy at 77-300 K. The properties of surface sites were preliminary characterized by the low temperature spectra of adsorbed CO, which reveal the presence of several types of Lewis acid sites of different strength, weak H-bond with surface OH-groups, as well as interaction with surface anions. Adsorption of isotopically substituted molecules: DCN, $\mathrm{H}^{13} \mathrm{C}^{14} \mathrm{~N}$ and $\mathrm{H}^{12} \mathrm{C}^{15} \mathrm{~N}$ facilitates the assignment of absorption bands and has shown that hydrogen cyanide does not dissociate on adsorption. Adsorbed molecules form coordinate bond with surface cations, interact with surface hydroxyls or form weak H-bond by the CH-group with the anions, apparently, with surface $\mathrm{F}^{-}$ions.

Keywords: IR spectroscopy, adsorption, magnesium fluoride, hydrogen cyanide, surface.

For citation: Rudakova A. V., Belykh R. A., Tsyganenko A. A. FTIR study of HCN adsorption on magnesium fluoride. Vestnik of Saint Petersburg University. Physics and Chemistry. 2018. Vol. 5 (63), iss. 2. P. 114-126. https://doi.org/10.21638/11701/spbu04.2018.205

\section{А. В.Рудакова, Р. А. Бельх, А. А. Цъцаненко}

\section{ИССЛЕДОВАНИЕ АДСОРБЦИИ НСN НА ФТОРИДЕ МАГНИЯ МЕТОДОМ ИК-ФУРЬЕ-СПЕКТРОСКОПИИ}

Санкт-Петербургский государственный университет,

Российская Федерация, 199034, Санкт-Петербург, Университетская наб., 7-9

\begin{abstract}
Методом ИК-фурье-спектроскопии при температурах 77-300 K изучен механизм взаимодействия $\mathrm{HCN}$ с $\mathrm{MgF}_{2}$, предварительно вакуумированным при $773 \mathrm{~K}$. Свойства поверхности охарактеризованы при помощи низкотемпературных спектров адсорбированного СО, которые показали наличие нескольких типов кислотных центров Льюиса разной силы, слабой Н-связи с поверхностными ОН-группами, а также взаимодействия с поверхностными анионами. Адсорбция изотопно замещённых молекул $\mathrm{DCN}, \mathrm{H}^{13} \mathrm{C}^{14} \mathrm{~N}$ и $\mathrm{H}^{12} \mathrm{C}^{15} \mathrm{~N}$ облегчает отнесение полос поглощения и показывает, что HCN при адсорбции не диссоциирует. Адсорбированные молекулы образуют координационную связь с катионами поверхности, взаимодействуют с гидроксилами поверхности или образуют слабую Н-связь СН-группы с анионами, очевидно, поверхностными ионами $\mathrm{F}^{-}$.

Ключевые слова: ИК-спектроскопия, адсорбция, фторид магния, цианистый водород, поверхность.

Для цитирования: Рудакова А. В., Белъх Р. А., Цыганенко А. А. Исследование адсорбции $\mathrm{HCN}$ на фториде магния методом ИК-фурье-спектроскопии // Вестник Санкт-Петербургского университета. Физика и химия. 2018. Т. 5 (63). Вып. 2. С. 114-126.

https://doi.org/10.21638/11701/spbu04.2018.205
\end{abstract}

Introduction. Nowadays a vast experimental material on the studies of metal oxide surfaces is accumulated and analyzed. Surface properties of metal halides in particular, of fluorides, have been studied much poorer, despite their wide application in optical industry and great potential for catalysis.

$\mathrm{MgF}_{2}$ has a rutile type crystal lattice. It is an insulator with a broad band gap $(\approx 12.6 \mathrm{eV})$, chemically and thermally very stable (melting point $1673 \mathrm{~K})$. It is transparent over an extremely wide frequency region and can be used as an optical material in

(C) Санкт-Петербургский государственный университет, 2018 
the wavelength range from $0.120 \mu \mathrm{m}$ in vacuum ultraviolet up to $8.0 \mu \mathrm{m}\left(1250 \mathrm{~cm}^{-1}\right)$ in the infrared.

Surface properties of $\mathrm{MgF}_{2}$ have been studied by Wojciechowska et al. by IR spectroscopy, thermo-desorption and thermo-graphic methods [1-4]. Several types of hydroxyl groups and adsorbed water molecules of different strength, concentration and thermal stability were established, as well as two types of weak Lewis acid sites- coordinately unsaturated $\mathrm{Mg}^{2+}$ ions. After treating the sample at $673-773 \mathrm{~K}$ anionic defect sites $\mathrm{O}^{2-}$ can be formed from the hydrogen-bonded $\mathrm{OH}$ groups.

Recently the structure and properties of nanodisperse magnesium fluorides prepared by a novel sol-gel synthetic route were investigated by XRD, MAS NMR, TEM, FTIR spectroscopy [5, 6]. By changing the amount of water at constant stoichiometric amount of $\mathrm{HF}$, it is possible to tune the surface acidity of the resulting partialy hydroxylated magnesium fluorides. Low-temperature $(100 \mathrm{~K})$ FTIR spectroscopic study of CO adsorption on such $\mathrm{MgF}_{2}$ shows that this material possesses three kinds of Lewis acid sites, identified as 3-, 4and 5 -fold coordinated unsaturated magnesium atoms of the surface. It was reported that the strength of these Lewis acid sites is medium or weak, but their concentration is very high (5-6 sites $\left./ \mathrm{nm}^{2}\right)$. Both Lewis basic and acidic sites play a role in water adsorption [7].

It was shown that $\mathrm{MgF}_{2}$ is a good support for transition metal oxides such as $\mathrm{V}_{2} \mathrm{O}_{5}, \mathrm{WO}_{3}$, $\mathrm{MoO}_{3}, \mathrm{Cr}_{2} \mathrm{O}_{3}$ [8] and binary systems like $\mathrm{Cu}-\mathrm{Cr}_{2} \mathrm{O}_{3}$ and $\mathrm{Cu}-\mathrm{Mn}$ oxides [8, 9] as well as for metal catalysts like $\mathrm{Au}[10], \mathrm{Pd}$ and $\mathrm{Ru}[11,12] . \mathrm{Ru} / \mathrm{MgF}_{2}$ catalyst reveals significantly higher activity in hydrodesulfurization as compared with $\mathrm{Ru} / \mathrm{SiO}_{2}$ and $\mathrm{Ru} / \mathrm{Al}_{2} \mathrm{O}_{3}$ with the same amount of ruthenium [13].

As a catalyst $\mathrm{MgF}_{2}$ can promote addition reaction on multiple bonds, polycondensation and polymerization reactions $[2,14]$. Due to high concentration of acidic Lewis sites, magnesium fluoride demonstrates high catalytic activity in acidic catalytic reactions such as isomerization of cyclohexene into methylcyclopentane, hydrogen disproportionation [14]. Kemnitz et al. have shown that hydroxylated nanoscopic fluorides $\left(\mathrm{MgF}_{2}\right.$ and $\left.\mathrm{AlF}_{3}\right)$ can be successfully applied as highly active catalysts in the synthesis of vitamins $\mathrm{E}$ and $\mathrm{K}_{1}$ [15]. Moreover, the catalytic potential of these materials has been investigated using Friedel - Crafts alkylation of aromatic compounds [16].

Hydrogen cyanide is an important starting material in some industrial synthesis processes, is an undesired toxic byproduct in some others [17]. It has been identified in the gas phase of the interstellar medium, as well as in the comae of comets and is believed to be a key component in the synthesis of the first biologically important molecules [18]. There are few works on the IR studies of adsorbed HCN on porous glass [19], silica [20], supported metal catalysts [21] and alumina [22]. The only paper, as far as we know, where HCN adsorption was studied spectroscopically on metal halides, was the old one by Kozirovski and Folman [23].

In this work adsorption of hydrogen cyanide, $\mathrm{DCN}$, as well as $\mathrm{H}^{13} \mathrm{C}^{14} \mathrm{~N}$ and $\mathrm{H}^{12} \mathrm{C}^{15} \mathrm{~N}$ molecules on the surface of commercial $\mathrm{MgF}_{2}$ has been studied by means of low temperature IR spectroscopy. To characterize adsorption properties of the surface, the spectra of $\mathrm{CO}$ adsorbed at $77 \mathrm{~K}$ have been preliminarily obtained before exposure the samples to HCN.

Experimental. The stainless steel cell used for low-temperature measurements was described elsewhere [24]. Pressure was measured with two Edwards Barocel 600 pressure gauges attached to the cell. One, with the accuracy of $10^{-3}$ Torr and the upper measurement limit of 10 Torr, was connected directly with the inner volume of the cell, and another for 1-1000 Torr was used to measure the pressure of the gas to be admitted from the dosing volume. 
In our experiments at $77 \mathrm{~K}, \mathrm{HCN}$ gas was usually let into the cell cooled by liquid nitrogen, where about 0.5 Torr of helium was added for better thermal contact of the sample with the cooled environment. Then liquid nitrogen was removed and the cell was let heated until the bands of adsorbed species appear $(\approx 120 \div 130 \mathrm{~K})$, and the evolution of spectra with temperature was followed. Then cell was repeatedly cooled by liquid nitrogen. To change the HCN coverage the sample was raised to the warmer part of the tube for a controlled time. The desorbed gas was frozen on the cold walls of the cell and after every heating the spectrum recorded at $77 \mathrm{~K}$ showed a diminished quantity of the adsorbate. Temperature of samples was measured by a thermocouple inserted into the coolant compartment close to the sample holder.

The commercial pure grade magnesium fluoride $\left(\mathrm{MgF}_{2}\right)$ was used. The samples were pressed into thin $\left(20-70 \mathrm{mg} / \mathrm{cm}^{2}\right)$ pellets and outgassed in vacuum for 30 minutes at $773 \mathrm{~K}$, in some experiments at $973 \mathrm{~K}$.

Hydrogen cyanide was prepared by a dropwise addition of $\mathrm{H}_{2} \mathrm{SO}_{4}$ to $\mathrm{KCN}$, purified by vacuum distillation, and only the first portion of $\mathrm{HCN}$ used in experiments. DCN was prepared in a similar manner by using $\mathrm{D}_{2} \mathrm{SO}_{4} \cdot \mathrm{H}^{13} \mathrm{CN}\left(70 \%{ }^{13} \mathrm{C}\right)$ and $\mathrm{HC}^{15} \mathrm{~N}\left(99 \%{ }^{15} \mathrm{~N}\right)$ were prepared by catalytic reaction of $\mathrm{CO}$ with $\mathrm{NH}_{3}$ at $900-1100 \mathrm{~K}$ over $\gamma-\mathrm{Al}_{2} \mathrm{O}_{3}$ preliminary activated at the same temperature. Industrial isotopically substituted ${ }^{13} \mathrm{CO}$ with $70-\%$ enrichment for the synthesis of $\mathrm{H}^{13} \mathrm{CN}$ and ${ }^{15} \mathrm{NH}_{3}$ with $99-\%$ enrichment for $\mathrm{HC}^{15} \mathrm{~N}$ were taken as initial substances for the synthesis reaction. The synthesized HCN was purified from carbon dioxide and ammonia by outgasing at about $180 \mathrm{~K}$ in a trap with ethyl alcohol cooled by liquid nitrogen, and dried over $\mathrm{P}_{2} \mathrm{O}_{5}$.

Spectra were recorded by a Nicolet-710 FTIR spectrometer with a coolable MCT detector, typically at $4 \mathrm{~cm}^{-1}$ spectral resolution by co-adding 128 scans.

Results. 1. $\boldsymbol{C O}$ adsorption. In the spectrum of $\mathrm{MgF}_{2}$, pretreated at 773 and cooled to $77 \mathrm{~K}$ strong bands occur at 3617,1665 and $1007 \mathrm{~cm}^{-1}$ accompanied by less intense peaks at $3590,3517,3400,3255$ with a shoulder at $3205 \mathrm{~cm}^{-1}, 2005,1240,992,899$ and $807 \mathrm{~cm}^{-1}$.

The changes of the spectrum caused by CO adsorption as well as the bands of adsorbed molecules are shown in Fig 1. Addition of about 10 Torr of CO does not affect the bands at 3617 and $1007 \mathrm{~cm}^{-1}$, while those at 3590 and $3205 \mathrm{~cm}^{-1}$ disappear. Intensity increase was detected at 3570 and $807 \mathrm{~cm}^{-1}$. Maxima at 3517 and $1240 \mathrm{~cm}^{-1}$ shift to 3507 and $1222 \mathrm{~cm}^{-1}$, respectively. The bands of adsorbed CO molecules arise at 2185, 2175, 2161, 2151 and $2140 \mathrm{~cm}^{-1}$.

Gradual removal of the adsorbate results first in the disappearance of the low frequency bands at 2140 and $2151 \mathrm{~cm}^{-1}$ simultaneously with the restoration of the $\mathrm{OH}$ bands at 3590 and $3205 \mathrm{~cm}^{-1}$, as well as the shift of the $3517 \mathrm{~cm}^{-1}$ band back to its initial position. Further surface coverage diminution leads to sequential removal of the 2161,2175 and $2185 \mathrm{~cm}^{-1}$ bands and to the high frequency shifts of their maxima to 2164,2183 and $2198 \mathrm{~cm}^{-1}$, respectively. The trace of the latter band can be seen at $2201 \mathrm{~cm}^{-1}$ after short pumping at $300 \mathrm{~K}$. It should be noted that the weakening and the shift of the latter band observed on coverage diminution is accompanied by intensity increase at the high-frequency side that is typical of lateral interaction between the adsorbed molecules [25]. Initial positions and intensities of the bands at 1240 and $807 \mathrm{~cm}^{-1}$ restore only after complete removal of adsorbed CO by pumping at $300 \mathrm{~K}$.

Pretreatment at $973 \mathrm{~K}$ leads to the disappearance of the most of above bands observed in the spectrum of initial sample, including the strongest bands at 3617,1665 and $1007 \mathrm{~cm}^{-1}$, only those at 992, 899 and near $807 \mathrm{~cm}^{-1}$, although of lower intensity, still remain in the spectrum. Bands of adsorbed CO also diminish and their relative intensities have changed, 


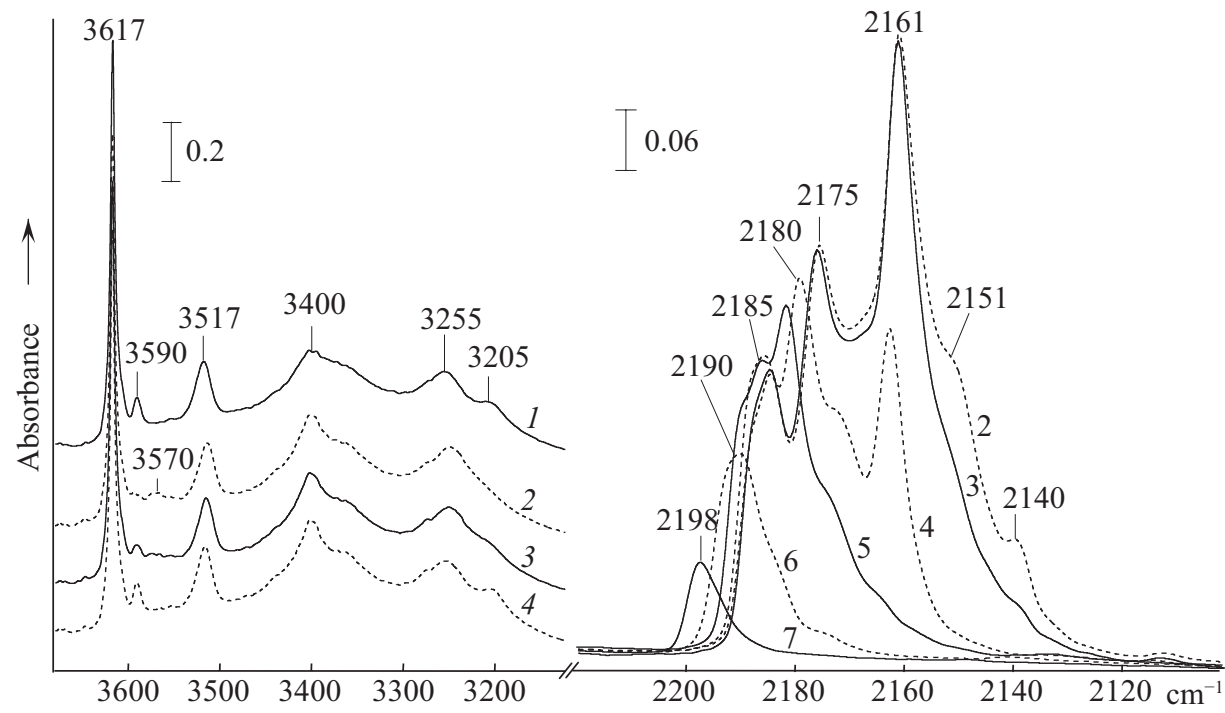

Fig. 1. IR spectra of $\mathrm{MgF}_{2}$ pretreated at $773 \mathrm{~K}$ :

1 - before and $2-7$ - after $\mathrm{CO}$ adsorption at different coverages

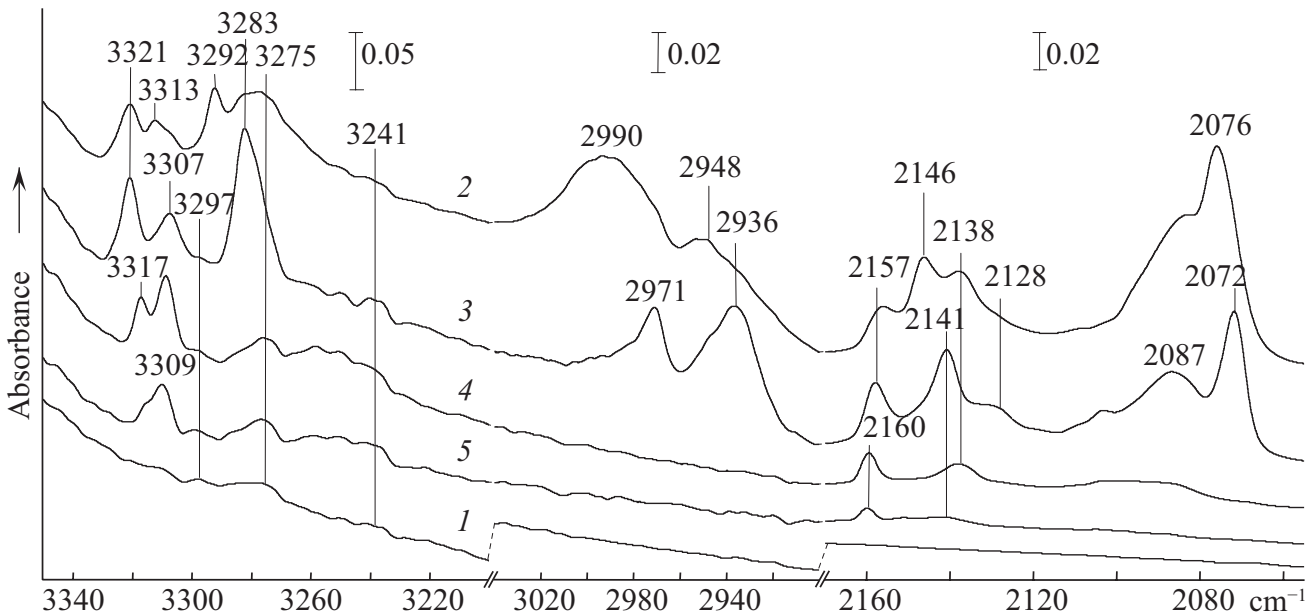

Fig. 2. IR spectra of $\mathrm{MgF}_{2}$ pretreated at $773 \mathrm{~K}$ :

1 - before and 2-5 - after HCN adsorption at different coverages; spectra were recorded at $77 \mathrm{~K}$; $\mathrm{HCN}\left(\approx 6.5 \cdot 10^{-5} \mathrm{~mole} / \mathrm{g}\right)$ was adsorbed at $150 \mathrm{~K}$

as compared with the spectrum of $\mathrm{MgF}_{2}$ evacuated at $773 \mathrm{~K}$. Maxima at 2175 and $2161 \mathrm{~cm}^{-1}$ become predominating while others, including those at 2185 and $2140 \mathrm{~cm}^{-1}$ remain as their shoulders.

2. HCN adsorption. $\mathrm{HCN}$ addition into the cell with $\mathrm{MgF}_{2}$ sample at $190 \mathrm{~K}$ does not influence the $\mathrm{OH}$ band at $3617 \mathrm{~cm}^{-1}$, but results in the diminution of that at $3590 \mathrm{~cm}^{-1}$, and increase of bands at 3518 and $3400 \mathrm{~cm}^{-1}$. Fig. 2 shows the bands of adsorbed molecules and their evolution on coverage decrease. It should be noted that the exact positions of the bands vary with the amount of adsorbate and depend on temperature that for the 
spectra in the figure was fixed at $77 \mathrm{~K}$. Curve 2 was obtained immediately after lowering the temperature in the presence of a dose of hydrogen cyanide with admitted helium, while curves 3-5 show the result of sequential desorption of HCN. Several groups of bands can be separated according to their stability. The first to disappear are those at $3292-3275 \mathrm{~cm}^{-1}$, 2087-2072 $\mathrm{cm}^{-1}$ and a broad band centered at $2990-2950 \mathrm{~cm}^{-1}$ with a "hole" at $2960 \mathrm{~cm}^{-1}$. In the difference spectra a band at about $883 \mathrm{~cm}^{-1}$ can also be distinguished.

As soon as the sample has been raised for 1 minute to the quartz tube kept at $298 \mathrm{~K}$, great changes occur in the spectrum of adsorbed molecules. The total intensity of the bands at 2083, 2076 and $883 \mathrm{~cm}^{-1}$ diminishes, their maxima move to 2087, 2072 and $879 \mathrm{~cm}^{-1}$, respectively. Instead of the doublet at 2146 and $2138 \mathrm{~cm}^{-1}$, we have one band at $2141 \mathrm{~cm}^{-1}$. Just the same, a band at $3283 \mathrm{~cm}^{-1}$ replaces the doublet at 3292 and $3277 \mathrm{~cm}^{-1}$. Intensity redistribution occurs within the 3321-3307 and 2990-2950 $\mathrm{cm}^{-1}$ doublets, while the maxima of these bands become shifted to some extent.

With further coverage decrease the intensities of the bands diminish up to their final disappearance after prolonged evacuation at $300 \mathrm{~K}$. The first to disappear are the bands at 2990-2936, 2072 and $883 \mathrm{~cm}^{-1}$. Then, those at 3281 and $2141 \mathrm{~cm}^{-1}$ are gone. The last bands, still visible after $20 \mathrm{~min}$ of desorption at $300 \mathrm{~K}$ (Fig. 2, curve 5), are those at $3309 \mathrm{~cm}^{-1}$ and a weak maximum at $2160 \mathrm{~cm}^{-1}$.

3. Competitive adsorption of $H C N$ and $C O$. To identify the sites of HCN adsorption an experiment with $\mathrm{CO}$ and $\mathrm{HCN}$ co-adsorption on $\mathrm{MgF}_{2}$ has been carried out. A doze of HCN was first admitted to the sample at $193 \mathrm{~K}$, then the cell was cooled to $77 \mathrm{~K}$ and He was added. After registering the spectrum about 5 torr of $\mathrm{CO}$ was introduced into the cell and the dependence of spectrum on the amount of adsorbed HCN was studied. For that, the sample was raised to the warmer part of the central tube of the closed cell for progressively increasing time. The desorbing HCN was trapped on the walls of the cold part of the cell, while $\mathrm{CO}$ remained in gas phase, and after placing the sample back between the cold windows occupied the liberated sites. The results are shown in Fig. 3.

As seen from the figure, the bands at 2198-2187 and $2140 \mathrm{~cm}^{-1}$ that are clearly seen in the spectrum of $\mathrm{CO}$ adsorbed on pure sample (curve 1) do not arise at all after adsorption of carbon monoxide on the sample exposed to $\mathrm{HCN}$, while the intensity of the $2175 \mathrm{~cm}^{-1}$ band is seriously lowered. Short heating of the sample up to $300 \mathrm{~K}$ removes most of HCN molecules absorbing near $2100 \mathrm{~cm}^{-1}$ and a great deal of those which account for absorption near $2130 \mathrm{~cm}^{-1}$ This causes the growth of the $2175 \mathrm{~cm}^{-1}$ band of CO together with its shoulder at $2182 \mathrm{~cm}^{-1}$. After removal of weakly bonded CO (curve 4) the $2150 \mathrm{~cm}^{-1}$ band disappears, while the maximum of $2175 \mathrm{~cm}^{-1}$ band moves further, finally up to $2186 \mathrm{~cm}^{-1}$.

4. Adsorption of isotopically substituted HCN. DCN adsorption was studied on a sample of $\mathrm{MgF}_{2}$ deuterated by threefold $\mathrm{D}_{2} \mathrm{O}$ adsorption-pumping cycles at $300 \mathrm{~K}$, followed by final evacuation at $773 \mathrm{~K}$ or $973 \mathrm{~K}$. The results are presented in Fig. 4. Bands in the region of stretching $\mathrm{C}-\mathrm{H}$ vibration $\left(3320-2900 \mathrm{~cm}^{-1}\right)$ due to the presence of admixed $\mathrm{HCN}$ are identical to those of pure $\mathrm{HCN}$ adsorbed at the same conditions, while weak bands of stretching C-D modes superimpose with the strong bands of OD groups. That is why we show only the region of $\mathrm{C}-\mathrm{N}$ stretching mode, where a correspondence between the bands of usual and deuterated molecules can be seen.

The band of weakly bound form at $2076 \mathrm{~cm}^{-1}$ corresponds to comparatively sharp maximum at $1834 \mathrm{~cm}^{-1}$. Broader band at $2085 \mathrm{~cm}^{-1}$ correlates with even broader absorption around $1855 \mathrm{~cm}^{-1}$. Instead of the triplet at 2156,2146 and $2138 \mathrm{~cm}^{-1}$, we have a group of bands at 1968, 1955 and $1942 \mathrm{~cm}^{-1}$, while two maxima, which remain at lowest coverages at 2160 and $2138 \mathrm{~cm}^{-1}$, correspond to those at 1968 and $1951 \mathrm{~cm}^{-1}$. At high coverages 


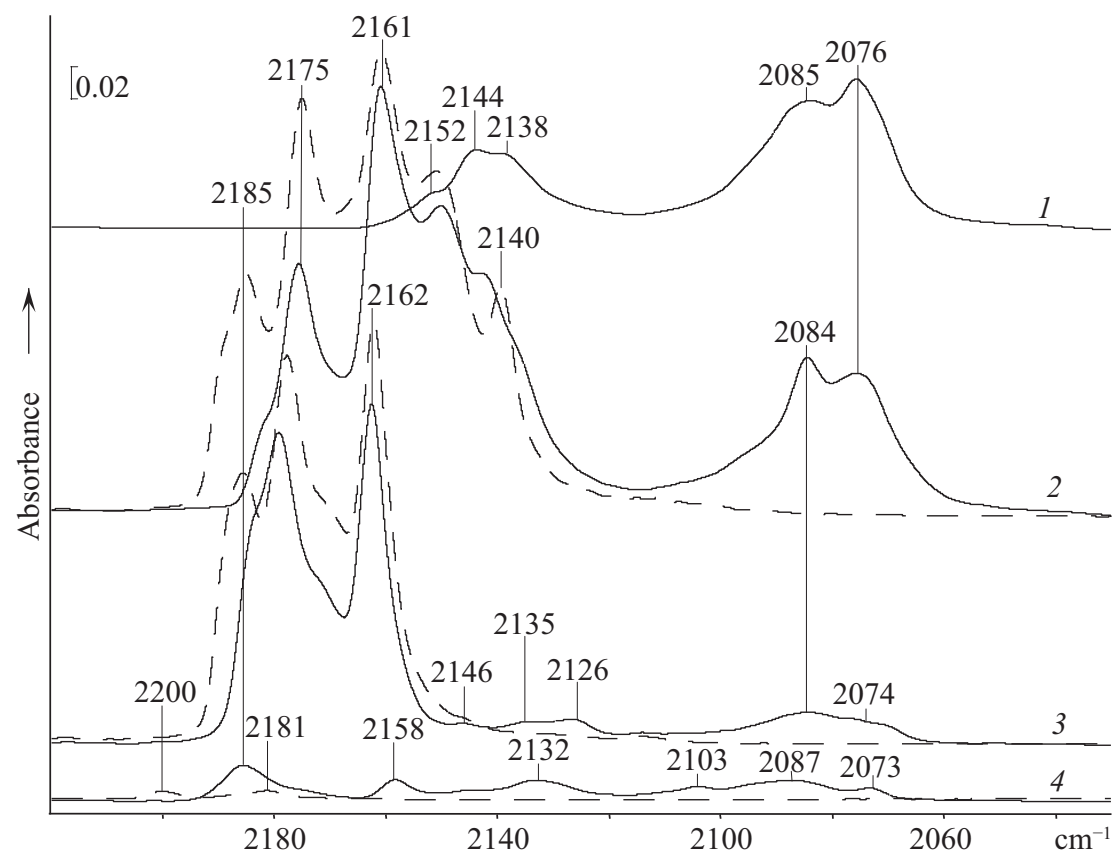

Fig. 3. IR spectra of $\mathrm{CO}$ adsorbed on the $\mathrm{MgF}_{2}$ surface with pre-adsorbed HCN (solid line): 1 - after HCN adsorption; 2 - after next CO adsorption; 3, 4 - at different HCN and CO coverages; IR spectra of $\mathrm{CO}$ adsorbed on pure $\mathrm{MgF}_{2}$ surface at the same conditions are presented by dashed lines

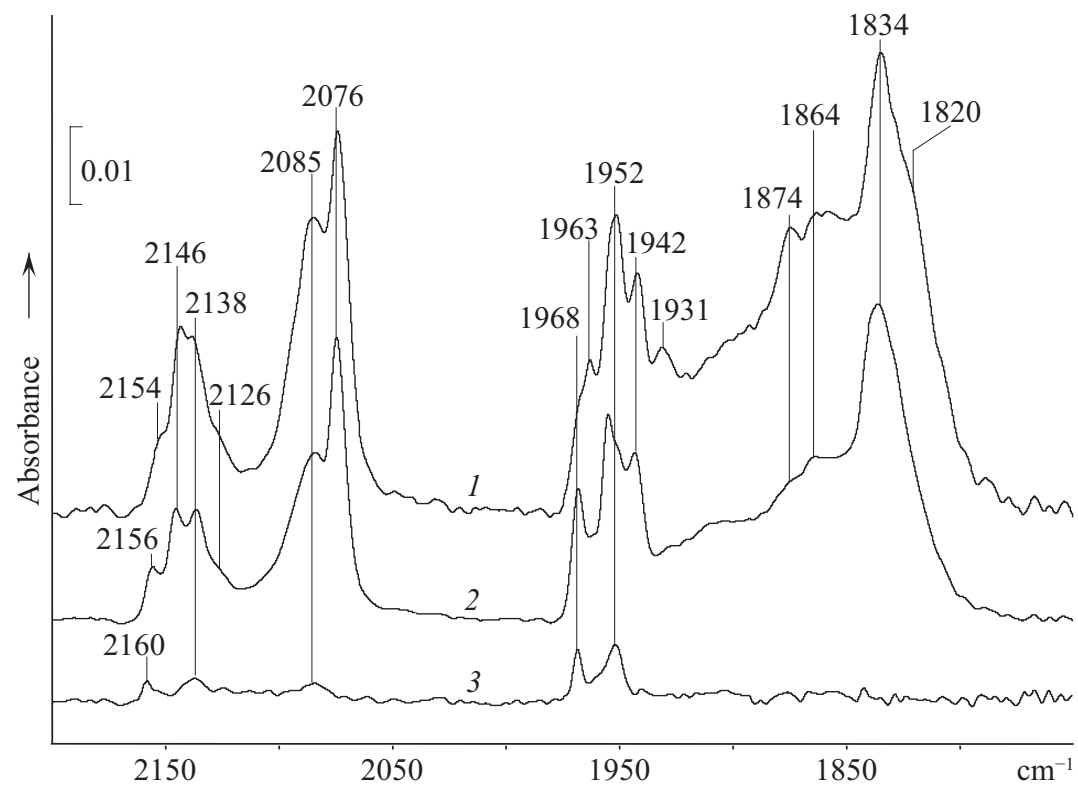

Fig. 4. IR spectra of $\mathrm{HCN} / \mathrm{DCN}$ adsorbed on $\mathrm{MgF}_{2}$ pretreated at $773 \mathrm{~K}$ at different $\mathrm{HCN}$ coverages:

spectra were recorded at $77 \mathrm{~K} ; \mathrm{HCN} / \mathrm{DCN}$ was adsorbed at $150 \mathrm{~K}$ 
two more bands can be distinguished at 2540 and $2482 \mathrm{~cm}^{-1}$ between the peaks of OD groups simultaneously with those of $\mathrm{HCN}$ at 2990 and $2948 \mathrm{~cm}^{-1}$. Thus, all the bands in the $2160-2070 \mathrm{~cm}^{-1}$ region have their analogs at $1970-1800 \mathrm{~cm}^{-1}$ in the spectra of adsorbed DCN.

Adsorption of $\mathrm{DCN}$ on $\mathrm{MgF}_{2}$ sample pretreated at $973 \mathrm{~K}$, where surface $\mathrm{OH}$-containing compounds are practically absent, leads to much simpler spectrum. The bands of residual HCN occur at $3183,2099 \mathrm{~cm}^{-1}$ and a weaker one at 2141, while the corresponding DCN peaks appear at 2570 and $1905 \mathrm{~cm}^{-1}$ with a shoulder at $1940 \mathrm{~cm}^{-1}$. No bands assignable to surface $\mathrm{OH}$ or $\mathrm{OD}$ groups or $\mathrm{CN}$-ions formed as a result of dissociative adsorption were detected neither after adsorption, nor after the removal of molecularly adsorbed cyanide by short pumping at room temperature.

Adsorption of $\mathrm{H}^{13} \mathrm{CN}$ with $70 \%$ isotopic enrichment (Fig. 5) results in the spectra where all the observed bands of adsorbed molecules appear in pairs corresponding to usual or substituted molecules. The bands of two isotopomers observed simultaneously in the region of C-H stretching vibrations are separated by $18-19 \mathrm{~cm}^{-1}$ : $\left(3320-3302 \mathrm{~cm}^{-1}, 3318-\right.$ $3299 \mathrm{~cm}^{-1}$; 3307 (curve 4 in Fig. 2) - 3287, 3292-3274, 3286-3268 $\mathrm{cm}^{-1}$ ). For the C-N stretching mode the isotopic shift is $30-34 \mathrm{~cm}^{-1}$ : $\left(2157-2124 \mathrm{~cm}^{-1}, 2138-2104 \mathrm{~cm}^{-1}, 2132-\right.$ $2098 \mathrm{~cm}^{-1}$, 2071-2041 $\mathrm{cm}^{-1}$ ). Application of ${ }^{15} \mathrm{~N}$ substituted hydrogen cyanide (Fig. 6) leads to the isotopic shift values of only $2-3 \mathrm{~cm}^{-1}$ for the bands near $3300 \mathrm{~cm}^{-1}$, while those at 2160-2075 $\mathrm{cm}^{-1}$ move to lower wavenumbers by $31-36 \mathrm{~cm}^{-1}$. The data on band positions and frequency shifts for the studied isotopomers of $\mathrm{HCN}$ adsorbed on different sites of $\mathrm{MgF}_{2}$ surface are summarized in Table, where for comparison the corresponding data for solid film (this work) as well as for the gaseous hydrogen cyanide are also presented.

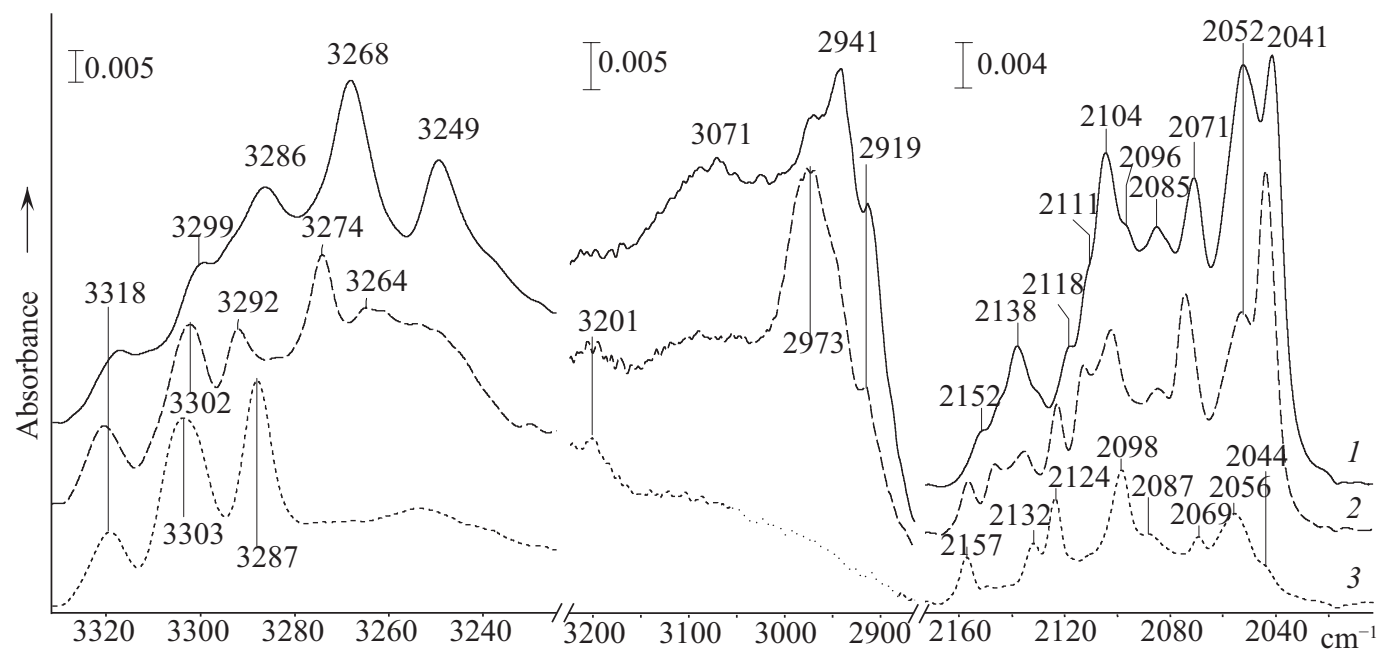

Fig. 5. FTIR spectra of $\mathrm{H}^{13} \mathrm{CN}$ adsorbed on $\mathrm{MgF}_{2}$ pretreated at $773 \mathrm{~K}$ at different coverages: spectra were recorded at $77 \mathrm{~K} ; \mathrm{H}^{13} \mathrm{CN}\left(5.05 \cdot 10^{-2} \mathrm{mmol} / \mathrm{g}\right)$ was adsorbed at $150 \mathrm{~K}$

Discussion. 1. Surface hydroxyl groups and CO adsorption. Spectra of the initial $\mathrm{MgF}_{2}$ samples are in accordance with the earlier reported results [1-3]. However, some authors assigned distinct bands in the $\mathrm{OH}$ stretching region $3750-3237 \mathrm{~cm}^{-1}$ to different types of hydroxyl groups on the surface of $\mathrm{MgF}_{2}$ microcrystals [1-4]. Others [6, 7] assign some of these bands to water molecules and distinguish adsorbed water, whose bands are 


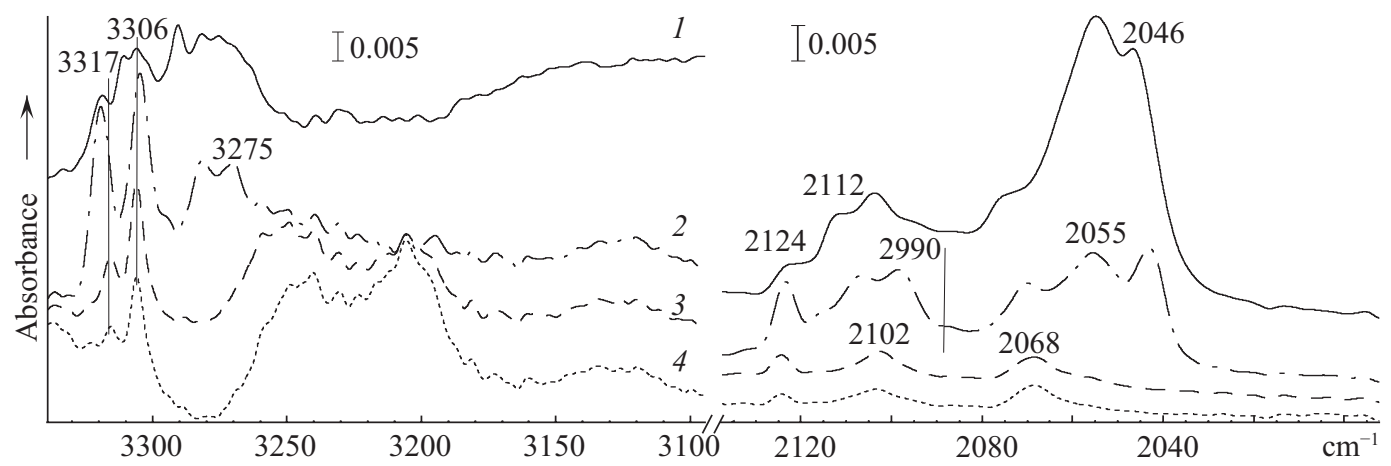

Fig. 6. FTIR spectra of $\mathrm{HC}^{15} \mathrm{~N}$ adsorbed on $\mathrm{MgF}_{2}$ pretreated at $773 \mathrm{~K}$ at different coverages: spectra were recorded at $77 \mathrm{~K} ; \mathrm{HC}^{15} \mathrm{~N}$ was adsorbed at $150 \mathrm{~K}$

Table

Band positions and frequency shifts for $\mathrm{HCN}$ gas, solid film and adsorbed on $\mathrm{MgF}_{2}$

\begin{tabular}{c|c|c|c|c|c|c|c}
\hline & $\mathrm{H}^{12} \mathrm{C}^{14} \mathrm{~N}$ & $\mathrm{D}^{12} \mathrm{CN}$ & $\Delta v$ & $\mathrm{H}^{13} \mathrm{C}^{14} \mathrm{~N}$ & $\Delta v$ & $\mathrm{H}^{12} \mathrm{C}^{15} \mathrm{~N}$ & $\Delta v$ \\
\hline \multirow{4}{*}{ Gas } & $3312^{*}$ & $2629^{*}$ & 683 & $3294^{* *}$ & 18 & $3310^{* *}$ & 2 \\
\cline { 2 - 8 } & $2089^{*}$ & $1921^{*}$ & 168 & $2055^{* *}$ & 34 & $2056^{* *}$ & 33 \\
\hline Film** & 3131 & 2552 & 579 & 3113 & 18 & 3125 & 6 \\
\cline { 2 - 8 } $77 \mathrm{~K}$ & 2100 & 1888 & 212 & 2067 & 33 & 2068 & 32 \\
\hline \multirow{4}{*}{$\begin{array}{c}\text { Adsorbed } \\
\text { on }\end{array}$} & 3317 & 2638 & 679 & 3303 & 14 & 3317 & 0 \\
\cline { 2 - 8 } & 3292 & - & - & 3268 & 24 & 3291 & 1 \\
\cline { 2 - 8 } & 3277 & - & - & 3249 & 28 & 3275 & 2 \\
\cline { 2 - 8 } & 2990 & 2540 & 450 & 2973 & 17 & 2990 & 0 \\
\cline { 2 - 8 } & 2160 & 1968 & 192 & 2124 & 36 & 2124 & 36 \\
\cline { 2 - 8 } & 2146 & 1942 & 204 & 2111 & 35 & 2112 & 34 \\
\cline { 2 - 8 } & 2084 & 1951 & 187 & 2098 & 40 & 2102 & 36 \\
\cline { 2 - 8 } & 2076 & 1864 & 220 & 2052 & 32 & 2055 & 29 \\
\hline
\end{tabular}

* [26]; ** this work.

sensitive to further adsorption (bands at 3590, 3225 and $1665 \mathrm{~cm}^{-1}$ ), and molecules trapped in the bulk (bands at 3515,3245 and $1650 \mathrm{~cm}^{-1}$, unsensitive to water adsorption). Our data on $\mathrm{CO}$ adsorption enable us to discriminate the $\mathrm{OH}$ bands according to their behavior. Strong bands at 3617 and $1007 \mathrm{~cm}^{-1}$, which are not sensitive to adsorption, should be assigned to the stretching and bending modes of $\mathrm{OH}$ groups, located rather in the bulk of microcrystals, apparently, replacing a part of fluorine anions. The bands at 3590 and $3205 \mathrm{~cm}^{-1}$, in contrast with those bands, disappear in the presence of CO and recover together on removal of weakly bound adsorbate, and thus, belong to surface $\mathrm{OH}$ containing species. Presence of two bands in the stretching $\mathrm{OH}$ region accompanied by the band at $1665 \mathrm{~cm}^{-1}$, the position quite typical of bending vibration of molecular water, enable us to associate these bands with the strongly held water molecules. This assignment is consistent with that of Wuttke et al. [7], who ascribe such bands to water molecules, which besides the coordinate bond to $\mathrm{Mg}^{2+}$ cation, form one or two $\mathrm{H}$ bonds with the neighboring $\mathrm{F}^{-}$anions.

Spectra of adsorbed CO reveal the presence of several different surface species formed on certain surface sites. The band arising at $2140 \mathrm{~cm}^{-1}$ in the presence of gaseous CO has its maximum slightly below the position of pure vibrational transition for CO gas $\left(2143 \mathrm{~cm}^{-1}\right)$. 
Such bands, usually assigned to physisorption, are often observed in the spectra of adsorbents with anionic centers and were shown to be due to side-on complexes of $\mathrm{CO}$ with surface basic sites, such as oxygen atoms of siloxane bridges or framework oxygen of basic zeolites [27], surface $\mathrm{OH}$ groups or of water molecules of disperse ice [28] or surface sulfur atoms of sulfides [29]. For $\mathrm{MgF}_{2}$, these basic sites could be surface $\mathrm{F}^{-}$ions or oxygen atoms of $\mathrm{OH}$ groups or water molecules.

$\mathrm{CO}$ interaction with the free $\mathrm{OH}$ groups, which is supposed above to belong to the coordinated water molecules, is evidenced by the perturbation of the $3590 \mathrm{~cm}^{-1}$ band in the presence of gaseous carbon monoxide. Weak H-bond of adsorbed $\mathrm{CO}$ with surface hydroxyls results in the low frequency shift of the O-H stretching vibration by about $90 \mathrm{~cm}^{-1}$ for silanol groups of silica [27] and $55 \mathrm{~cm}^{-1}$ for dangling $\mathrm{OH}$ groups of water ice [28] accompanied by the increase of band intensity. Simultaneously, the frequency of CO stretching vibration moves to higher wavenumbers up to 2160-2156 and $2153 \mathrm{~cm}^{-1}$, respectively. In our case, the band assignable to the perturbed $\mathrm{OH}$ groups appears at $3566 \mathrm{~cm}^{-1}$, shifted only by $20 \mathrm{~cm}^{-1}$, while the band of weakly bound CO occurs at $2151 \mathrm{~cm}^{-1}$, even lower than when adsorbed on dangling $\mathrm{OH}$ groups of water ice. It also disappears on the removal of $\mathrm{CO}$ gas, when the $3690 \mathrm{~cm}^{-1}$ band restores, and is less intense in the spectrum of sample dehydroxylated at $973 \mathrm{~K}$. This band can be, thus reasonably assigned to CO molecules adsorbed as proton acceptors on the poorly acidic $\mathrm{OH}$ groups. However, we have to adopt that some contribution to the absorption near $2151 \mathrm{~cm}^{-1}$ can be due to molecules adsorbed on very weak cationic centers, as far as the band at about the same position, although weak, remains in the spectrum of $\mathrm{CO}$ adsorbed on the sample pretreated at $973 \mathrm{~K}$, where the absorption of $\mathrm{OH}$ groups is negligible.

The position of CO band at $2165-2161 \mathrm{~cm}^{-1}$ is typical of molecules adsorbed on the medium-strength Bronsted acidic sites, but for $\mathrm{MgF}_{2}$ this band remains after the restoration of the initial spectrum in the $\mathrm{OH}$ region and is quite intense in spectrum of dehydroxylated sample. Thus, we have to assign it to CO molecules adsorbed on the weak Lewis sites, apparently 5-coordinated $\mathrm{Mg}^{2+}$ cations. Other two bands which move with coverage diminution from 2175 to 2182 and from 2185 finally to $2201 \mathrm{~cm}^{-1}$, are certainly due to molecules adsorbed on two kinds of stronger Lewis sites, presumably, 4- and 3-coordinated $\mathrm{Mg}^{2+}$ ions. The decrease of the relative intensity of the most high-frequency CO band, as well as those of bands at $2151-2140 \mathrm{~cm}^{-1}$ with respect to the intensities of bands at $2175-2161 \mathrm{~cm}^{-1}$ in the spectrum of sample pretreated at $973 \mathrm{~K}$, can be interpreted as lowering of the relative concentration of defect low-coordinated Lewis sites, $\mathrm{OH}$ groups and the most basic $\mathrm{F}^{-}$ions as a result of sintering and crystallization.

2. Hydrogen cyanide. Spectrum of a free $\mathrm{HCN}$ molecule in gas phase is rather simple. The bands of C-H and C-N stretching vibrations occur at 3312 and $2089 \mathrm{~cm}^{-1}$, respectively, while the band of degenerated bending mode can be seen at $712 \mathrm{~cm}^{-1}$ [26]. To explain the observed complex spectrum of adsorbed molecules, besides the surface heterogeneity, revealed by the spectra of adsorbed CO, we have to consider different mechanisms of adsorption.

There are various ways of HCN interaction with the surface of ionic solids (Fig. 7). The molecule can form coordinate bond (1) with cationic sites by the lone pair of nitrogen atom, which also acts as base when the molecule forms $\mathrm{H}$-bond with the acidic surface $\mathrm{OH}$ groups (2). H-bond can be formed by the molecule itself via the proton of its $\mathrm{CH}$ group with basic oxygen ions or $\mathrm{O}$ atoms of basic hydroxyl groups (3). One can adopt also side-on interaction with the anions (4). Dissociative adsorption on the metal-oxygen pair sites of oxides (5) leads to formation of surface $\mathrm{OH}$ groups and $\mathrm{CN}$-ions [30]. The latter can be bound to the surface via $\mathrm{C}$ or $\mathrm{N}$ atom, thus demonstrating linkage isomerism, previously established for 
CO molecules. Such two forms of HCN dissociative adsorption were reported for silica [20] and alumina [22]. It should be added that HCN molecule itself exists in two isomeric forms, HCN and HNC. The latter is energetically less stable and can be spectroscopically observed only at elevated temperatures [31]. However, for the adsorbed molecules it can be not so, and $\mathrm{HNC}$ isomer coordinately bound via $\mathrm{C}$ atom with strong Lewis acid sites could happen to become energetically favorable.

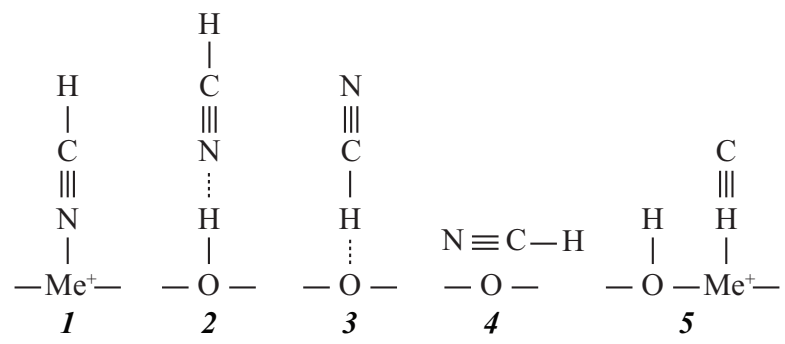

Fig. 7. Possible ways of HCN interaction with oxide surfaces

Spectral manifestations of different kinds of interaction have much in common and we often are not able to distinguish certain forms of adsorption basing only on the position of IR absorption bands. So, both coordination and H-bond lead to slight frequency increase for the CN stretching vibration, which occurs at the same wavenumbers, at about $2120-2050 \mathrm{~cm}^{-1}$ both for the molecule and $\mathrm{CN}$-ion or radical [32]. Maybe, only for the species H-bonded via $\mathrm{C}$-H group to surface oxygen atom one could anticipate a noticeable decrease of the $\mathrm{CH}$ stretching frequency, but the CN band of this form, apparently, should overlap with the bands of other weakly adsorbed molecules.

The data for unequivocal assignment of the observed bands could be obtained using adsorption of isotopically substituted molecules. Deuteration leads to a very large frequency shift of the CN stretching mode because of its strong interaction with the stretching CD vibration. This sensitivity to $\mathrm{H}-\mathrm{D}$ substitution can be used to distinguish between molecularly adsorbed species and $\mathrm{CN}$-ions, whose bands should not be affected by deuteration. Due to the high position of the $\mathrm{CH}$ stretching vibration $\left(3312 \mathrm{~cm}^{-1}\right.$ for $\mathrm{HCN}$ gas $)$ it is not easy to discriminate between the $\mathrm{CH}$ bands of adsorbed $\mathrm{HCN}$ and $\mathrm{NH}$ bands of HNC isomer, supposed to be formed or stabilized on strong Lewis sites. For that, adsorption of ${ }^{13} \mathrm{C}$ - or ${ }^{15} \mathrm{~N}$-labled molecules should be helpful. Accurate measurements of isotopic shifts caused by ${ }^{13} \mathrm{C}$ - and ${ }^{15} \mathrm{~N}$-substitution can provide information about the way of coordination of CN-ions. In fact, as shown by Yates and co-workers [22], shifts of the bands due to Ti-CN and Ti-NC species on ${ }^{13} \mathrm{C}$ substitution differ by about $10 \mathrm{~cm}^{-1}$, being, respectively, greater or smaller than for a free CN group, where it follows the change in the reduced mass.

The bands at $2104-2084 \mathrm{~cm}^{-1}$, which are among the first to disappear on evacuation, could be due to $\mathrm{HCN}$ adsorbed on the $\mathrm{OH}$ groups or weakly coordinated to surface cations. In fact, $\mathrm{HCN}$ adsorption on silanol groups of silica results in the band of H-bonded molecules at $2105 \mathrm{~cm}^{-1}$. Other bands of weakly bound molecules at 2990 and $2076 \mathrm{~cm}^{-1}$ because of the low frequency of $\mathrm{C}-\mathrm{H}$ vibration could be attributed to molecules $\mathrm{H}$-bonded to the surface anionic sites via the protons of $\mathrm{CH}$ group.

It should be noted, however, that $\mathrm{CN}$-ions in inorganic cyanides absorb in the same region, about $2240-2070 \mathrm{~cm}^{-1}$ [32]. HCN dissociation should lead to the appearance of new $\mathrm{OH}$ bands that was not detected for the samples pretreated at $973 \mathrm{~K}$. The data on DCN adsorption present the decisive argument for the assignment of all the bands observed in 
this region after adsorption of hydrogen cyanide to different forms of molecular adsorption. In fact, all the bands of adsorbed $\mathrm{HCN}$ in this region were found to have their analogs in the spectra of DCN shifted downwards by $168-242 \mathrm{~cm}^{-1}$. High sensitivity of C-N stretching mode to deuteration has two reasons. First, due to high frequency of $\mathrm{C}-\mathrm{H}$ and $\mathrm{C}-\mathrm{D}$ vibrations as compared with that of $\mathrm{C}-\mathrm{N}$ mode, the $\mathrm{CH}$ or $\mathrm{CD}$ groups move with respect to $\mathrm{N}$ atom together as an atom with the mass 13 or 14, respectively. This leads to the increase of the reduced mass, and hence, a frequency shift. The latter, however, in this case should not exceed $40 \mathrm{~cm}^{-1}$. Much greater isotopic effect is caused by strong interaction between C-D and $\mathrm{C}-\mathrm{N}$ stretching modes in a linear molecule, leading to mutual repulsion of the frequencies of the two normal vibrations. As a result, the ratio of $\mathrm{C}-\mathrm{H}$ and $\mathrm{C}-\mathrm{D}$ stretching frequencies is smaller, while for the $\mathrm{C}-\mathrm{N}$ vibration is greater than it follows from the reduced masses of corresponding diatomics. This effect is particularly strong for the case of molecules $\mathrm{H}$-bonded to the surface anions, where the $\mathrm{C}-\mathrm{H}$ frequency is already lowered due to the hydrogen bond. It is, thus not by chance that for this form of adsorption the shift of $v \mathrm{CN}$ band on deuteration is extremely large, from 2076 to $1834 \mathrm{~cm}^{-1}$ and the shift of C-H band at about 2990 to $2540 \mathrm{~cm}^{-1}$ (see Table) is small as compared with the bands of other HCN species.

One more peculiarity of this form of adsorption is in the shape of the $v \mathrm{CH}$ band (curves 2 and 3 in Fig. 2) that is split by a "hole" at $2960 \mathrm{~cm}^{-1}$. This phenomenon is rather typical of the contours of the X-H bands in the case of strong hydrogen bonds. So called "Evans' holes" arise due to Fermi resonance with the combinations of low frequency vibrations in the H-bonded complexes. In our case the combination of $2076 \mathrm{~cm}^{-1}$ with the $883 \mathrm{~cm}^{-1}$ mode gives almost exactly $2960 \mathrm{~cm}^{-1}$.

Another band of weakly bound molecules at $2084 \mathrm{~cm}^{-1}$ together with the accompanied peak at $3292 \mathrm{~cm}^{-1}$ and, perhaps also at $3283 \mathrm{~cm}^{-1}$, are rather due to molecules adsorbed on surface $\mathrm{OH}$ groups, since these bands are absent in the spectra of sample pretreated at $973 \mathrm{~K}$, where no bands of surface hydroxyls were detected. Stronger held HCN species with sharp $\mathrm{CH}$ bands at $3321-3307 \mathrm{~cm}^{-1}$ and the bands of C-N vibrations at $2160-2128 \mathrm{~cm}^{-1}$ should be assigned to molecules bound to the coordinately unsaturated surface $\mathrm{Mg}^{2+}$ cations. This is supported by the data on competitive HCN and CO adsorption. In fact, removal of HCN leading to the decrease of these bands results in the intensity increase of the bands at 2185 and $2175 \mathrm{~cm}^{-1}$ due to $\mathrm{CO}$ molecules adsorbed on $\mathrm{Mg}^{2+}$ sites with different coordination number.

The question about possible appearance of isomeric HNC molecules coordinately bound to $\mathrm{MgF}_{2}$ surface can be cleared up with the help of the data on the adsorption of ${ }^{13} \mathrm{C}$ and ${ }^{15} \mathrm{~N}$ substituted molecules. As seen from Table, for all the observed bands in the $3320-2900 \mathrm{~cm}^{-1}$ region the shifts caused by ${ }^{15} \mathrm{~N}$ substitution do not exceed $2 \mathrm{~cm}^{-1}$, while those caused by $\mathrm{H}^{13} \mathrm{CN}$ adsorption are between 14 and $28 \mathrm{~cm}^{-1}$. This means that all these bands are due to the $\mathrm{C}-\mathrm{H}$ stretching modes of $\mathrm{HCN}$ molecules coordinated to $\mathrm{Mg}^{2+}$ ions via nitrogen.

Conclusions. FTIR spectra of $\mathrm{MgF}_{2}$ pretreated at 773 or $973 \mathrm{~K}$, as well as those of $\mathrm{CO}$ adsorbed at $77 \mathrm{~K}$ on the material are in accordance with the results of earlier studies and provide evidence for the existence of surface $\mathrm{OH}$ containing species and cationic electronaccepting (Lewis acid) sites of several kinds. The study of $\mathrm{HCN}$ interaction with $\mathrm{MgF}_{2}$ reveals a complex picture of plenty different adsorbed species. Weakly bound molecules form $\mathrm{H}$-bond with surface $\mathrm{OH}$-groups or interact with surface anions, presumably F-ions, via hydrogen bond of $\mathrm{CH}$-group as a proton donor. The data of DCN adsorption supports this result and testify for the absence of dissociative adsorption in agreement with the data on the sample pretreated at $973 \mathrm{~K}$. Adsorption of $\mathrm{H}^{13} \mathrm{C}^{14} \mathrm{~N}$ and $\mathrm{H}^{12} \mathrm{C}^{15} \mathrm{~N}$ has shown that 
hydrogen cyanide does not undergo isomeric transition with the formation of HNC species coordinately bonded to strong Lewis sites.

\section{References}

1. Wojciechowska M. Hydroxyl groups on the surface of magnesium fluoride. Bull. Acad. Polon. Ser. Sci. Chim., 1981, vol. 29 (11-12), pp. 531-547.

2. Wojciechowska M., Fiedorov R. Surface chemistry of porous magnesium fluoride. J. Fluorine Chem., 1980, vol. 15 , pp. 443-452.

3. Wojciechowska M. Modification of magnesium fluoride surface by impregnation with oxo-acid. Bull. Acad. Polon. Ser. Sci. Chim., 1981, vol. 29 (11-12), pp. 549-562.

4. Wojciechowska M., Czajka B., Pietrowski M., Zielinski M. $\mathrm{MgF}_{2}$ as a non-conventional catalytic support. Surface and structure characterization. Catal. Lett., 2000, vol. 66, pp. 147-153.

5. Wuttke S., Scholz G., Rudiger S., Kemnitz E. Variation of sol-gel synthesis parameters and their consequence for the surface area and structure of magnesium fluoride. J. Mater. Chem., 2007, vol. 17, pp. 4980-4988.

6. Wuttke S., Coman S. M., Scholz G., Kirmse H., Vimont A., Daturi M., Schroeder S. L. M., Kemnitz E. Novel sol-gel synthesis of acidic $\mathrm{MgF}_{2-x}(\mathrm{OH})_{x}$ materials. Chem. Eur. J., 2008, vol. 14, pp. 11488-11499.

7. Wuttke S., Vimont A., Lavalley J.-C., Daturi M., Kemnitz E. Infrared investigation of the acid and basic properties of a sol-gel prepared $\mathrm{MgF}_{2}$. J. Phys. Chem. (C), 2010, vol. 114 (11), pp. 5113-5120.

8. Wojciechowska M., Zielinski M., Pietrovski M. $\mathrm{MgF}_{2}$ as a non-conventional catalyst support. J. Fluorine Chem., 2003, vol. 120, pp. 1-11.

9. Wojciechowska M., Haber J., Lomnicki S., Stoch J. Structure and catalytic activity of double oxide system: $\mathrm{Cu}-\mathrm{Cr}-\mathrm{O}$ supported on $\mathrm{MgF}_{2}$. J. Mol. Catal. (A), 1999. vol. 141 (1-3), pp. 155-170.

10. Negoi A., Wuttke S., Kemnitz E., Macovei D., Parvulescu V. I., Teodorescu C. M., Coman S. M. One-pot synthesis of menthol catalyzed by a highly diastereoselective $\mathrm{Au} / \mathrm{MgF}_{2}$ catalyst. Angew. Chem. Int. Ed., 2010, vol. 49, pp. 8134-8138.

11. Wojciechowska M., Pietrowski M., Lomnicki S. Novel supported catalyst for hydrodesulfurization reaction. Chem. Commun., 1999, pp. 463-464.

12. Malinowski A., Juszczyk W., Pielaszek J., Bonarowska M., Wojciechowska M., Karpinski Z. Magnesium fluoride as a catalytic support in hydrodechlorination of $\mathrm{CCl}_{2} \mathrm{~F}_{2}$ (CFC-12). Chem. Commun., 1999, pp. 685-686.

13. Wojciechowska M., Pietrowski M., Czajka B. New supported ruthenium catalyst for hydrodesulfurization reaction. Catal. Today, 2001, vol. 65 (2-4), pp. 349-253.

14. Wojciechowska M., Fiedorov R., Kania W. Wlasnosci powierzchni i aktywnosc katalityczna fluozku magnezu. Chemia Stosowana, 1977, vol. 21 (3-4), pp. 431-439.

15. Coman S. M., Parvulescu V. I., Wuttke S., Kemnitz E. Synthesis of vitamin $\mathrm{K}_{1}$ and $\mathrm{K}_{1}$-chromanol by Friedel - Crafts alkylation in heterogeneous catalysis. Chem. Cat. Chem., 2010, vol. 2 (1), pp. 92-97.

16. Candua N., Wuttke S., Kemnitz E., Coman S. M., Parvulescua V. I. Friedel - Crafts alkylations on nanoscopic inorganic fluorides. Appl. Cat. (A), 2011, vol. 391 (1-2), pp. 169-174.

17. Szanyi J., Kwak J.H., Peden C.H.F. The catalytic chemistry of $\mathrm{HCN}+\mathrm{NO}_{2}$ over Na- and $\mathrm{Ba}-\mathrm{Y}$, FAU: An in situ FTIR and TPD/TPR study. J. Phys. Chem. (B), 2005, vol. 109, pp. 1481-1490.

18. Gerakines P. A., Moore M. H., Hudson R. L. Ultraviolet photolysis and proton irradiation of astrophysical ice analogs containing hydrogen cyanide. Icarus, 2004, vol. 170, pp. 202-213.

19. Kozirovski Y., Folman M. Infra-red spectrum and surface polymerization of adsorbed HCN. Trans. Faraday Soc., 1964, vol. 60 (9), pp. 1532-1538.

20. Morrow B. A., Cody I. A. Infra-red studies of reactions on oxide surfaces. Part 3. $\mathrm{HCN}$ and $\mathrm{C}_{2} \mathrm{~N}_{2}$ on silica. J. Chem. Soc. Faraday Trans. I, 1975, vol. 71, pp. 1021-1032.

21. Rasko J., Bansagi T., Solymosi F. HCN adsorption on silica and titania supported Rh catalysts studied by FTIR. Phys. Chem. Chem. Phys., 2002, vol. 4 (14), pp. 3509-3513.

22. Kim S., Sorescu D. C., Yates J. T., Jr. Infrared spectroscopic study of HCN adsorption on clean and triethylenediamine-precovered $\gamma-\mathrm{Al}_{2} \mathrm{O}_{3}$ : Competition with triethylenediamine for adsorption sites. J. Phys. Chem. (C), 2007, vol. 111 (49), pp. 18226-18235.

23. Kozirovski Y., Folman M. Infrared spectrum and spectral shifts of HCN adsorbed on evaporated alkali halides. Trans. Faraday Soc., 1966, vol. 62 (4), pp. 808-820.

24. Tsyganenko A. A. Variable temperature IR spectroscopy in the studies of oxide catalysts. Topics in Catalysis, 2013, vol. 56 (11), pp. 905-913.

25. Dobrotvorskaia A. N., Pestsov O.S., Tsyganenko A. A. Lateral interaction between molecules adsorbed on the surfaces of non-metals. Topics in Catalysis, 2017, vol. 60 (19-20), pp. 1506-1521. 
26. Sverdlov L. M., Kovner M. A., Krainov E. P. Vibrational Spectra of Polyatomic Molecules. New York, Wiley. 1972.

27. Tsyganenko A. A., Kondratieva E. V., Yanko V.S., Storozhev P. Yu. FTIR study of CO adsorption on basic zeolites. J. Mater. Chem., 2006, vol. 16, pp. 2358-2363.

28. Rudakova A. V., Sekushin V. N., Marinov I. L., Tsyganenko A. A. The preparation and IR spectroscopic testing of surface of pure water ice and icy mixtures with prussic acid and ammonia. Langmuir, 2009, vol. 25 (3), pp. 1482-1487.

29. Tsyganenko A. A., Can F., Travert A., Maugé F. FTIR study of unsupported molybdenum sulfide - in situ synthesis and surface properties characterization. Appl. Catal. (A), 2004, vol. 268 (1-2), pp. 189-197.

30. Tsyganenko A. A., Chizhik A. M., Chizhik A. I. A FTIR search for linkage isomerism of CN-ions on oxides and zeolites. Phys. Chem. Chem. Phys., 2010, vol. 12 (24), pp. 6387-6395.

31. Maki G., Sams R. L. High temperature, high resolution infrared spectral measurements on the HNC-HCN equilibrium system. J. Chem. Phys., 1981, vol. 75 (9), pp. 4179-4182.

32. Nakamoto K. Infrared and Raman spectra of inorganic and coordination compounds. $4^{\text {th }} e d$. New York; Chichester; Brisbane; Toronto; Singapore, J. Willey \& Sons. 1986A.

Received: 14.05 .2018$.

Контактная информация

Aida V. Rudakova — PhD; e-mail: arudakova@mail.ru

Roman A. Belykh — post-graduate student; e-mail: beroal.mail@gmail.com

Alexey A. Tsyganenko — Dr. Sci. in Physics and Mathematics, Professor; e-mail: atsyg@yandex.ru

Рудакова Аида Виталъевна - канд. хим. наук; e-mail: arudakova@mail.ru

Бельх Роман Александрович - аспирант; e-mail: beroal.mail@gmail.com

Цыганенко Алексей Алексеевич - д-р физ.-мат. наук, проф.; e-mail: atsyg@yandex.ru 